\title{
PEMBAGIAN ANTROPOLOGI HUKUM
}

\author{
Aziz Alhuda \\ alhuda.aziz03@gmail.com \\ 2010003600236 \\ Universitas Ekasakti
}

\begin{abstract}
Legal Anthropology as the study of human behavior in all its aspects is related to empirically written and unwritten legal norms. In an anthropological perspective, law is a cultural activity that functions as a means of social control, or it can be used as a tool to maintain social order in the community. The Study of Legal Anthropology has provided an analysis of the results of creation, distribution and transmission. existing law. Study of how the rule of law processes and impacts each society. Next will show how the feed back and the influence of the communities.
\end{abstract}

Key words: Anthropology of Law

\section{Abstrak}

Antropologi Hukum sebagai ilmu mempelajari perilaku dari manusia dengan segala macam aspeknya terkait norma-norma hukum tertulis maupun tidak tertulis secara empiris. Dalam perspektif antropologis, hukum merupakan aktifitas kebudayaan yang berfungsi sebagai sarana pengendalian sosial (social control), atau bisa dekatakan juga sebagai alat untuk menjaga keteraturan sosial (social order) dalam lingkungan masyarakat.Pengkajian Antropologi Hukum telah memberikan telaah akan hasil kreasi, distribusi dan transmisi hukum yang ada. Kajian mengenai bagaimana kekuasaan hukum berproses dan memberi dampak dalam masing-masing masyarakat. Selanjutnya akan menampilkan bagaimana feed back dan pengaruh masyarakatmasyarakat.

Kata kunci: Antropologi hukum

\section{A. PENDAHULUAN}

Secara etimologis antropologi berasal dari bahasa Yunani, yaitu "Anthropos" yang berarti manusia dan "Logos" berarti ilmu pengetahuan. Jadi, antropologi merupakan ilmu yang mempelajari manusia. Oleh karena itu antropologi didasarkan pada kemajuan yang telah dicapai ilmu pengetahuan sebelumnya. Menurut David Hunter antropologi 
adalah ilmu yang lahir dari keingintahuan yang tidak terbatas tentang umat manusia. Antropologi menurut Koentjaraningrat adalah ilmu yang mempelajari umat manusia pada umumnya dengan mempelajari aneka warna, bentuk fisik masyarakat serta kebudayaan yang dihasilkan. Dari beberapa definisi tersebut dapat disimpulkan bahwa antropologi merupakan sebuah ilmu yang mempelajari manusia dari segi keanekaragaman fisik serta kebudayaan seperti cara berperilaku, tradisi-tradisi dan nilainilai yang dihasilkan, sehingga setiap manusia yang satu dengan yang lainnya dapat diketahui perbedaannya.

Antropologi Hukum sebagai ilmu dipengaruhi oleh Antropologi dan Ilmu Hukum, sehingga Antropologi Hukum dianggap sebagai "anak", ia mempunyai "bapak" Antropologi dan "ibu” Ilmu Hukum, maka dapat disimpulkan bahwa prasyarat untuk bisa mengerti tentang Antropologi Hukum adalah dengan memahami Antropologi dan Ilmu Hukum terlebih dahulu. Antropologi Hukum sebagai ilmu mempelajari perilaku dari manusia dengan segala macam aspeknya terkait norma-norma hukum tertulis maupun tidak tertulis secara empiris. Antropologi hukum mempelajari hukum dari latar belakang kultur masyarakat tertentu, baik pada masyarakat sederhana maupun masyarakat modern. Dengan kata lain, Antropologi Hukum merupakan Antropologi yang mempelajari Hukum sebagai salah satu aspek dari kebudayaan.

Berdasarkan pendekatan Antropologi Hukum, hukum pada dasarnya berbasis pada masyarakat. Hal itulah, yang membuat Antropologi Hukum dibagi ke dalam beberapa model-model populer, antara lain yaitu kerja lapangan (fieldwork methodology), penggunaan pendekatan holistik (holistic approach), model atau metode perbandingan 
hukum (comparative method) dan model yang fokus terhadap proses-proses mikro (micro processes).

\section{B. PEMBAHASAN}

Antropologi hukum merupakan ilmu pengetahuan (logos) tentang manusia (antropos) terkait dengan hukum. Manusia yang dimaksud pada penjelasan tersebut adalah manusia yang hidup dalam masyarakat dan bergaul antara yang satu dengan yang lainnya, baik masyarakat tersebut masih sederhana budayanya (primitif) maupun yang sudah modern budayanya (maju). Budaya yang dimaksud pada penjelasan tersebut adalah budaya hukum, yaitu berbagai macam bentuk perilaku dari budaya manusia yang berkaitan maupun mempengaruhi dengan masalah hukum.

Masalah hukum yang dimaksud pada penjelasan tersebut bukan saja hukum dalam bentuk dan arti perilaku sebagai kebiasaan yang terjadi berulang-ulang, sebagaimana dalam hukum adat atau hukum dalam arti dan bentuk kaidah peraturan perundangan, dengan demikian bisa dikatakan sebagai hukum dengan pendekatan yang normatif. Tetapi juga masalah hukum yang dilihat dari segi-segi kecendikiawan (intelektual), filsafat, ilmu jiwa dan lainnya dalam konteks hukum itu serta cara-cara menyelesaikan sesuatu perselisihan yang timbul dalam masyarakat.

Dalam perspektif antropologis, hukum merupakan aktifitas kebudayaan yang berfungsi sebagai sarana pengendalian sosial (social control), atau bisa dekatakan juga sebagai alat untuk menjaga keteraturan sosial (social order) dalam lingkungan masyarakat. Hal itu yang membuat hukum dipelajari sebagai bagian yang integral dari kebudayaan secara keseluruhan, bukan sebagai suatu institusi otonom yang terpisah dari 
segi-segi kebudayaan yang lainnya. Jadi, sebelum memahami tempat hukum yang ada dalam struktur masyarakat, maka harus dipahami terlebih dahulu kehidupan sosial dan budaya masyarakat tersebut secara keseluruhan. Seperti yang dikatakan oleh Hoebel (1954) "We must have a look at society and culture at large in order to find the place of law within the total structure. We must have some idea of how society works before we can have a full conception of what law is and how it works".

Hal ini memperlihatkan, bahwa hukum menjadi salah satu produk kebudayaan yang tidak bisa dipisahkan dari segi-segi kebudayaan yang lain, seperti ekonomi, politik, struktur dan organisasi sosial, ideologi, religi, dsb. Untuk memperlihatkan keterkaitan hukum dengan aspek-aspek kebudayaan lainnya, maka menarik untuk mengungkapkan teori hukum sebagai suatu sistem (the legal system) seperti yang dikemukakan oleh Friedman (1975: 14-5, 1984: 5-7) seperti berikut:

1) Hukum sebagai suatu sistem pada dasarnya memiliki tiga elemen, yaitu (a) struktur sistem hukum (structure of legal system) yang terdiri dari lembaga pembuat undangundang (legislatif), institusi pengadilan dengan strukturnya, kejaksaan dengan strukturnya, badan kepolisian negara yang berfungsi sebagai aparat penegak hukum; (b) substansi sistem hukum (substance of legal system) berupa norma-norma hukum, peraturan-peraturan hukum serta termasuk pola-pola perilaku masyarakat yang berada di balik sistem hukum; dan (c) budaya hukum masyarakat (legal culture) seperti nilai-nilai, ide-ide, harapan-harapan dan kepercayaan-kepercayaan yang terwujud dalam perilaku masyarakat dalam mempersepsikan hukum.

2) Setiap masyarakat memiliki struktur dan substansi hukum sendiri. Sikap dan perilaku sosial masyarakatlah yang menentukan apakah substansi dan struktur hukum tersebut 
ditaati atau sebaliknya juga dilanggar dan karena itu untuk memahami apakah hukum itu menjadi efektif atau tidak sangat tergantung pada kebiasaan-kebiasaan (customs), kultur (culture), tradisi-tradisi (traditions), dan norma-norma informal (informal norms) yang diciptakan dan dioperasionalkan dalam masyarakat yang bersangkutan. Dengan mengkaji komponen struktur hukum, substansi hukum, dan kultur hukum sebagai suatu sistem hukum, maka dapat dicermati bagaimana suatu sistem hukum bekerja dalam masyarakat, atau bagaimana sistem-sistem hukum dalam konteks pluralisme hukum saling berinteraksi dalam suatu bidang kehidupan sosial (social field) tertentu. Kultur hukum menjadi bagian dari kekuatan sosial yang menentukan efektif atau tidaknya hukum dalam kehidupan masyarakat. Kultur hukum menjadi motor penggerak dan memberi masukanmasukan kepada struktur dan substansi hukum dalam memperkuat sistem hukum. Kekuatan sosial secara terus menerus mempengaruhi kinerja sistem hukum, yang kadangkala dapat merusak, memperbaharui, memperkuat, atau memilih lebih menampilkan segi-segi tertentu, sehingga dengan mengkaji komponen substansi, struktur, dan budaya hukum berpengaruh terhadap kinerja penegakan hukum, maka dapat dipahami suatu situasi bagaimana hukum bekerja sebagai suatu sistem dalam kehidupan masyarakat (Friedman, 1984:12).

Berdasarkan pendekatan Antropologi Hukum, hukum pada dasarnya berbasis pada masyarakat. Sehingga Antropologi Hukum dibagi menjadi beberapa model-model yang populer, yaitu sebagai berikut:

Pertama, kerja lapangan. Kerja lapangan (fieldwork methodology) merupakan salah satu model atau metode studi yang khas dalam Antropologi Hukum. Model ini 
ditujukan untuk memahami eksistensi dan bekerjanya hukum dalam situasi normal maupun suasana sengketa.

Kedua, penggunaan pendekatan holistik (holistic approach). Ini merupakan ciri khas yang lain dari Antropologi Hukum. Model ini selalu mengkaitkan fenomena hukum dengan aspek-aspek kebudayaan yang lain, seperti ekonomi, politik, organisasi sosial, religi, ideologi, dsb. Dalam investigasi dan analisis bekerjanya hukum dalam masyarakat.

Ketiga, model atau metode perbandingan hukum (comparative method). Model ini beroperasi dengan melakukan studi perbandingan antara sistem-sistem hukum dalam masyarakat yang berbeda-beda di berbagai belahan dunia. Dalam kaitan dengan yang disebut terakhir, hukum adat di Indonesia tidak sama dengan Antropologi Hukum, karena hukum adat hanya salah satu dari sistem hukum rakyat (folk law atau customary law) yang menarik untuk dikaji melalui studi Antropologi Hukum, seperti juga sistem-sistem hukum rakyat asli (indigenous law) yang dapat ditemukan di Malaysia, Philipina, Thailand, Nepal, India, Australia, Amerika Latin, Afrika, dsb. dengan menggunakan metode studi perbandingan (comparative study). Jadi, hukum adat (adat law) merupakan sistem hukum khas Indonesia yang bisa digunakan sebagai obyek kajian untuk memahami sistem hukum-hukum rakyat yang secara empiris hidup dan berkembang dalam kehidupan masyarakat sebagai cerminan pluralisme hukum dalam masyarakat di berbagai wilayah di Indonesia.

Keempat, model yang memfokuskan pada proses-proses mikro. Karakter khas lain dari Antropologi Hukum adalah berbagai sistem hukum dalam masyarakat di berbagai belahan dunia dipelajari dengan memfokuskan pada proses-proses mikro (micro processes) yang secara empiris berlangsung dalam kehidupan masyarakat. Karena itu, 
metode holistik dalam mengkaji kemajemukan hukum dalam masyarakat sangat membantu menjelaskan mekanisme, prosedur, dan institusi-institusi hukum dan bekerjanya hukum serta keterkaitannya dengan aspek politik, ekonomi, religi, organisasi sosial, ideologi, dsb.

Keterkaitan dari karakteristik model-model atau metodologi Antropologi Hukum seperti disebutkan di atas adalah: jika studi-studi mengenai fenomena hukum dalam masyarakat dilakukan untuk memperoleh pemahaman secara utuh-menyeluruh dan holistik, maka studi Antropologi Hukum harus difokuskan paling tidak pada empat aspek kajian pokok sekaligus (sebagai satu kesatuan), yaitu mulai dari kajian-kajian sebagai berikut:

1. Proses pembuatan hukum (Law making process)

2. Norma hukum/ Peraturan Perundang-undangan (Legal Norms)

3. Pelaksanaan hukum (Law implementation/application)

4. Penegakkan hukum (Law enforcement).

Dalam aspek lain, apakah masyarakat secara konsisten mematuhi dan mentaati hukum yang mengatur perilaku mereka, sehingga dapat dicermati apakah hukum berlaku secara efektif atau mungkin berlangsung sebaliknya menjadi tidak efektif. Pada tingkatan ini akan dapat dipahami bagaimana aspek-aspek ekonomi, politik, sosial, religi, sosial, bahkan ideologi partai atau tekanan negara/lembaga internasional mempengaruhi kinerja pelaksanan hukum maupun penegakan hukum berlangsung dalam masyarakat.

Selain itu, dapat dikritisi dengan pendekatan Antropologi Hukum apakah hukum negara cenderung mendominasi, menggusur, mengabaikan Atau memarjinalisasi eksistensi hak-hak masyarakat lokal dan sistem hukum rakyat (adat) dalam proses 
implementasi dan penegakan hukum negara melalui politik pengabaian kemajemukan hukum (the political of legal pluralism ignorance)? Atau mungkin berlangsung dan diberlakukan secara berdampingan (co-existance) dalam suasana yang harmoni? Pertanyaan-pertanyaan tersebut dapat dialamatkan oleh kita sebagai peneliti yang memfokuskan perhatian pada Antropologi Hukum.

\section{PENUTUP}

Dari penjelasan di atas dapat di ketahui bahwa hukum pada dasarnya berbasis pada masyarakat. Karena itu, Antropologi Hukum dibagi menjadi beberapa model-model yang popular, salah satu dari model atau metode yang khas dalam Antropologi Hukum adalah kerja lapangan (fieldwork methodology), untuk memahami eksistensi dan bekerjanya hukum dalam situasi normal maupun sengketa.

Pengkajian Antropologi Hukum telah memberikan telaah akan hasil kreasi, distribusi dan transmisi hukum yang ada. Kajian mengenai bagaimana kekuasaan hukum berproses dan memberi dampak dalam masing-masing masyarakat. Selanjutnya akan menampilkan bagaimana feed back dan pengaruh masyarakat-masyarakat. 


\section{DAFTAR PUSTAKA}

Prof.Dr.Tajul Arifin, M. (2016). Antropologi Hukum Islam. Bandung: Pusat Penelitian dan Penerbitan.

Harniwati, Peralihan Hak Ulayat Menurut Undang-Undang Nomor 18 Tahun 2004, Volume 1, Nomor 3, 2019.

Jasmir, Pengembalian Status Hukum Tanah Ulayat Atas Hak Guna Usaha, Soumatera Law Review, Volume 1, Nomor 1, 2018.

Jumrawarsi Jumrawarsi, Neviyarni Suhaili, Peran Seorang Guru Dalam Menciptakan Lingkungan Belajar Yang Kondusif, Ensikopedia Education Review, Vol 2, No 3 (2020): Volume 2 No.3 Desember 2020

Mia Siratni, Proses Perkawinan Menurut Hukum Adatdi Kepulauan Mentawai Di Sebelum Dan Sesudah Berlakunya Undang-Undang Nomor 1 Tahun 1974 Tentang Perkawinan, Ensiklopedia Of Journal, Vol 1 No 2 Edisi 2 Januari 2019,

Remincel, Dimensi Hukum Pelanggaran Kecelakaan Lalu Dan Angkutan Jalan Lintas Di Indonesia, Ensiklopedia Social Review, Volume 1, Nomor 2, 2019.

R Amin, B Nurdin, Konflik Perwakafan Tanah Muhammadiyah di Nagari Singkarak Kabupaten Solok Indonesia 2015-2019, Soumatera Law Review, Volume 3, Nomor 1, 2020. 